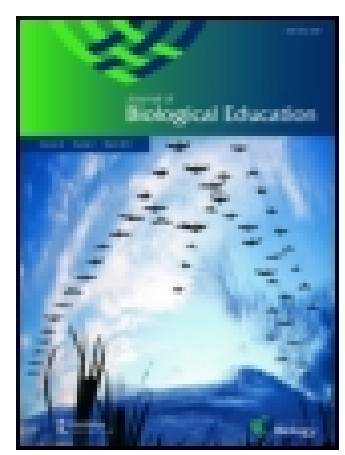

Journal of Biological Education

\title{
Misconceptions in biology: a meta-synthesis study of research, 2000-2014
}

\section{Bahar Kumandaş, Armagan Ateskan \& Jennie Lane}

To cite this article: Bahar Kumandaș, Armagan Ateskan \& Jennie Lane (2018): Misconceptions in biology: a meta-synthesis study of research, 2000-2014, Journal of Biological Education, DOI: 10.1080/00219266.2018.1490798

To link to this article: https://doi.org/10.1080/00219266.2018.1490798

曲 Published online: 03 Jul 2018.

Submit your article to this journal

Џll Article views: 317

View Crossmark data $₫$ 


\title{
Misconceptions in biology: a meta-synthesis study of research, 2000-2014
}

\author{
Bahar Kumandaş, Armagan Ateskan (iD and Jennie Lane (iD \\ Graduate School of Education, Bilkent University, Ankara, Turkey
}

\begin{abstract}
Teachers need to be aware of biology misconceptions in their classrooms and how to address them. In response, researchers and science educators have suggested and examined effective practices to prevent and ameliorate misconceptions. An extensive review of the literature gives researchers and educators insights into trends, practices, and gaps in the misconceptions research and helps decide which issues to address and why. The current study shares how researchers in Turkey conduct a content analysis of published misconception research in Turkey by using a form. The analysis resulted in a meta-synthesis (thematic content analysis) that inventoried and compared the purposes, research methods, data collection instruments, and findings of the selected publications. Biology educators in other regions of the world can inform their practice by using this instrument and research methods to learn about trends and patterns in misconception research. Researchers will gain insights into effective methods that have been used to examine misconceptions and will be able to identify biology misconceptions that have been under-investigated and need further analysis.
\end{abstract}

\section{KEYWORDS}

Biology misconceptions;

content analysis; meta-synthesis; Paper

Classification Form

\section{Introduction}

Awareness of and issues with misconceptions and student learning have been noted in the literature for many years (Caravita and Halldén 1994; Driver and Easley 1978; Monteiro et al. 2012). Yip (1998) explains that misconceptions are the thoughts and ideas posed by students that are inconsistent with scientific knowledge. Student misconceptions may arise from their experiences, the language used during daily communications, their teachers' content knowledge and their textbooks (Ault 1984; King 2009). Students develop concepts at an early age as they explore their physical and social world. Children's misconceptions about natural phenomena often develope before they participate in formal schooling (Driver 1988). A number of studies have noted, however, that teachers may possess misconceptions that can be the cause of students' alternative ideas (Larkin 2012). When these alternate conceptions make perfect sense to learners they are particularly difficult to change or shed (Allen 2010).

Misconceptions compromise learning, especially meaningful learning. More than just memorising facts, meaningful learning takes place when students make connections between previous understanding and new knowledge (Driver 1989). If the existing concepts students possess are flawed or incorrect, the foundation on which they build new information will in turn be compromised (Vosniadou 1994). 
In addition to identifying students' alternative ideas, there have been investigations in how to address and correct misconceptions (Tanner and Allen 2005; Tekkaya 2002). The results of these studies and others discuss how the following strategies can help correct students' misconceptions: concept mapping (Kinchin 2000; Novak and Gowin 1984; Ross and Munby 1991; Sanders 1993), stories and explanations that challenge misconceptions (Johnstone, McAlpine, and MacGuire 1986; Novak and Musonda 1991), and predict-observe-explain activities (Bilen, Köse, and Uşak 2011; Liew and Treagust 1995).

While students can have misconceptions in any discipline, they are often investigated in the sciences, including biology. The content and complexity of biological concepts and the abstract or hidden aspects of natural phenomenon cause biology to be an especially hard subject to teach and to learn (Bennett 2003; Brown and Schwartz 2009; Rotbain, Marbach-Ad, and Stavy 2008; Schmid and Telaro 1990; Sesli and Kara 2012). Many notable studies have discussed strategies to identify misconceptions in biology (Kinchin 2000; Liu and Lee 2013; Pearsall, Skipper, and Mintzes 1997; Pugh, Koskey, and Linnenbrink-Garcia 2014). Likewise, there have been studies focusing on how to address and change student alternative biology conceptions (Duit and Treagust 2003; Kubisch and Heyne 2016; Lucero and Petrosino 2017; Wandersee, Mintzes, and Novak 1994). Students can form alternative ideas about biological functions in the human body (hormones, the nervous system, reproduction), genetics (mitosis, meiosis, mutations), ecology (natural selection, food webs), and so forth. More advanced topics and new technologies such as those related to genetic engineering and bioinformatics are adding more complications to the (Johnston and Mahmoud 1980; Tekkaya, Özkan, and Sungur 2001). Given the increase in research related to biology misconceptions, there is a need to review these studies to better inform teacher educators, teachers and pre-service teachers about themes and patterns, we can more effectively address student misconceptions, and ideally prevent them from forming in the first place.

In Turkey, biology concepts are first introduced to students during primary school in a subject called Life Science. Biology lessons continue within science classes in the middle school. In high school, students take formal biology classes and some students focus mainly on biology during their last two years of schooling. Students wishing to become biology teachers in Turkey take science and biology courses at the beginning of their undergraduate studies and then take pedagogy courses in their last year at university.

Turkish educators and researchers have been investigating misconceptions in biology learning for several years (Çelikler and Aksan 2011; Güneş et al. 2010; Özay and Öztaş 2003; Tekkaya, Çapa, and Yılmaz 2000; Yakışan, Selvi, and Yürük 2007). However, a comprehensive review of these studies has yet to be conducted. The current study provides an overview of a variety of published research of misconceptions in biology. It adapted and used a tool called the Paper Classification Form to inventory and analyse the studies. By categorising practices and patterns, this inquiry will inform educators about efforts taken to identify and address misconceptions. Researchers can use the results to gain insights into the methods and extent of misconception research. The following research question and sub-questions guided the investigation:

How does the adapted Paper Classification Form facilitate a meta-synthesis study of published research about misconceptions in biology?

- What are the purposes of research studies on misconceptions in biology?

- What are the characteristics of research studies on misconceptions in biology with regard to research methods, the sample and size, data collection tools and data analysis methods?

- What are the trends and patterns in research studies on misconceptions in biology?

\section{Method}

Through a content analysis of selected published studies, this study identified trends and patterns in research related to biology misconceptions in Turkey. Neuendorf (2002) defines content analysis as 'a 
summarizing, quantitative analysis of messages that relies on the scientific method and is not limited as to the types of variables that may be measured or the context in which the messages are created or presented' (10). Krippendorff (2004) states that content analysis is 'a research technique for making replicable and valid inferences from texts (or other meaningful matter) to the context of their use' (18).

Overall, analysing published literature involves reviewing articles to identify overarching patterns and conclusions. Çalık and Sözbilir (2014) have grouped content analysis under three subheadings: descriptive content analysis, meta-analysis, and meta-synthesis. In this study, the research design is meta-synthesis, which involves analysing and evaluating a group of studies that are conducted within the same domain (Çalık and Sözbilir 2014). Typically, a meta-synthesis entails reviewing hundreds of articles. Since a limited number of articles $(N=67)$ were analysed in the current study, a more specific description of the design is: An in-depth investigation and interpretation of selected articles through meta-synthesis.

\section{Method of data collection}

Relevant articles for the current study were collected primarily through academic search engines. The following databases were used for this study: Institute for Scientific Information (ISI), Web of Science, Scopus, EBSCOhost, ULAKBİM and Academia Social Science (ASOS) Index. The main search terms used were 'Biology' and 'misconceptions.' Follow up searches were conducted using other terms for misconception cited in the literature, such as alternative conceptions (Hewson and Hewson 1983) and misunderstanding.

In addition to limiting articles to biology misconception research, other parameters were set for the investigation. Firstly, only articles published in or about Turkey were selected. Secondly, to explore only twenty-first century trends in biology misconceptions, publication dates were restricted to 2000 to 2014. Thirdly, the search was limited to research-based studies only and did not include theoretical studies. Finally, only investigations that involved elementary, middle and high school students, and pre-service teachers were considered. As a result of this search and screening process, 67 published articles were identified for the content analysis.

To review and analyse the articles, the researchers received permission to adapt and use the Paper Classification Form (PCF) (given in Appendix 1) developed by Sözbilir, Kutu, and Yaşar (2012). To ensure the validity of the instrument in addressing the research questions, the instrument was adapted to better categorise the articles. The most important alteration was to include identification of the biological concepts addressed. Items about data collection tools, research method and data analysis method were also slightly adapted or shortened.

To measure the reliability, 8 (12\%) of the sampled articles were selected randomly and, along with the instrument, given to biology educators and students who were earning their master's degree in biology education. They were instructed to use the instrument to analyse the articles. The results were compared with the researchers' findings and any differences were discussed. Discussions resulted in either an adjustment to the PCF or reviewing the analyses until consensus was reached.

\section{Data analysis}

The research questions for this study guided the organisation of the content analysis data. Once the revised Paper Classification Form was found to be reliable, the researchers used it for each of the 67 articles. The forms were reviewed to develop coding categories; these codes were based on the form itself supported with a review of the literature (Prasad 2008). As codes were developed, new categories were created and some of them were changed according to the needs of this study. In this study, codes were tabulated through the descriptive statistics by using Excel and the Statistical Package for Social Science (SPSS) package, version 19.0. 


\section{Results}

Of the 67 articles reviewed for this study, the largest number were published in 2013 (20.9\%) and no study was published 2001. Figure 1 shows the percentage of articles published about misconception in biology from 2000 to 2014.

Regarding the target audiences of the studies, around $41 \%$ of the articles were conducted with pre-service teachers. There were also studies that worked with middle school (25\%) and high school (23.5\%) students. A few of the studies (5.9\%) collected data from elementary school students. Most of the studies used samples ranging from 31 to 100 participants. The next most commonly used sample sizes ranged from 101 to 300 (28.4\%). Less than $2 \%$ of the studies sampled fewer than 10 participants; a comparably small number of studies were conducted with over 1000 participants.

The research methods used by the articles were classified as qualitative, quantitative and mixed research methods. Among the articles investigated, $43 \%$ were qualitative and $45 \%$ quantitative; only $12 \%$ used mixed methods. Among the articles using quantitative methods (solely or mixed), 25.4\% employed descriptive and $28.2 \%$ used inferential statistics.

The analysis shows that the most popular data collection tools were achievement tests (17.8\%), diagnostic tests (18.7\%) and interviews (11.9\%). In addition, most of the reviewed studies were conducted using a single data collection tool (55.4\%), while $35.5 \%$ used a combination of two different data tools. Just over $9 \%$ of the studies relied on three or four data collection tools. Figure 2 shows the types of questions used within achievement, diagnostic, attitude and conceptual understanding tests. The studies that use these types of questions were categorised based on the following question types: multiple choice, open ended, two-tier multiple choice and Likert type. The most popular question types were multiple choice (41\%) and open-ended (38\%). Two-tier multiple choice (8\%) and Likert type (6\%) questions were used less frequently.

The content analysis was also used to categorise the different purposes of the selected studies (see Figure 3). The target of most of the articles was to identify the misconception under investigation $(44.1 \%)$. Around $20.2 \%$ of the articles focused on a treatment to observe the effectiveness of an instructional strategy to prevent or eliminate misconceptions. A similar amount of the articles (19.1\%) investigated cognitive structures.

There were 21 articles that investigated conceptual change strategies. As shown in Table 1, the number of studies that focused on this approach became more popular over time, starting with only two studies during the period of 2000-2004 and increasing to 19 in 2010-2014. These studies were categorised into nine areas: analogy and modelling, computer and laboratory, concept cartoon, concept

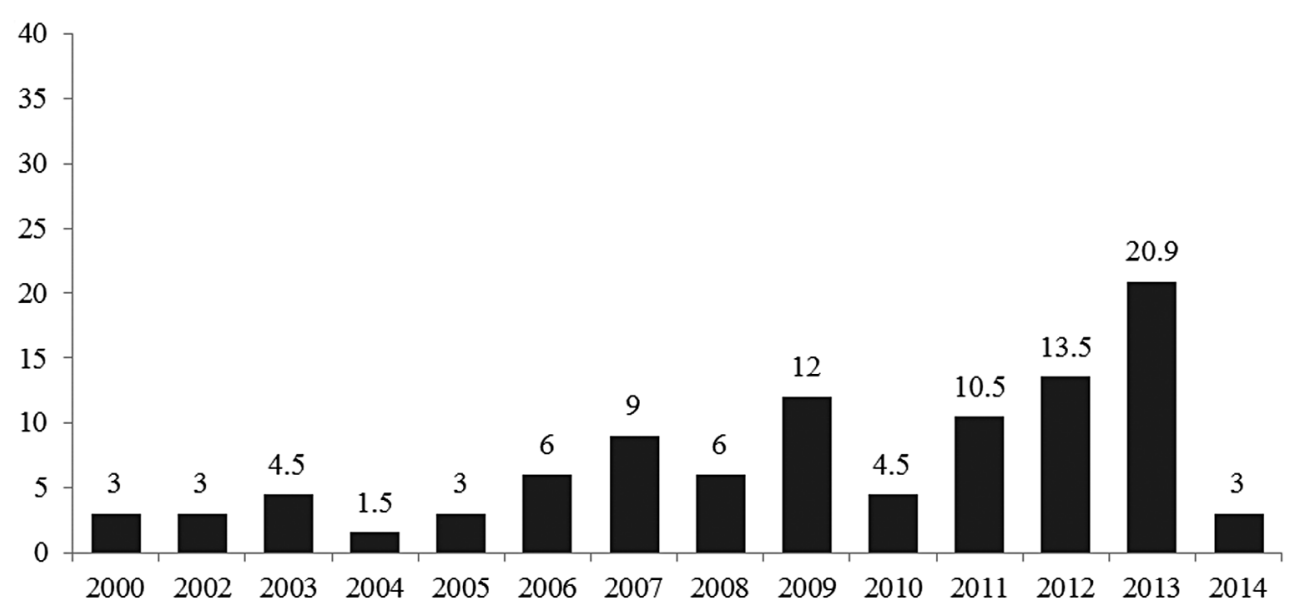

Figure 1. Percentages of studies across years (2000-2014). 


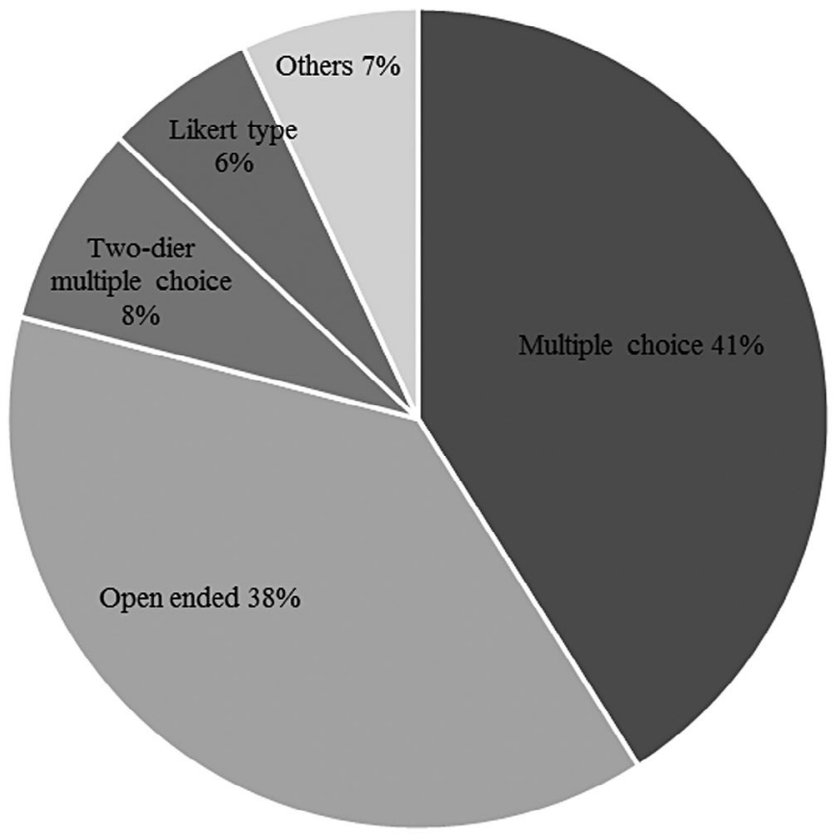

Figure 2. Types of questions.

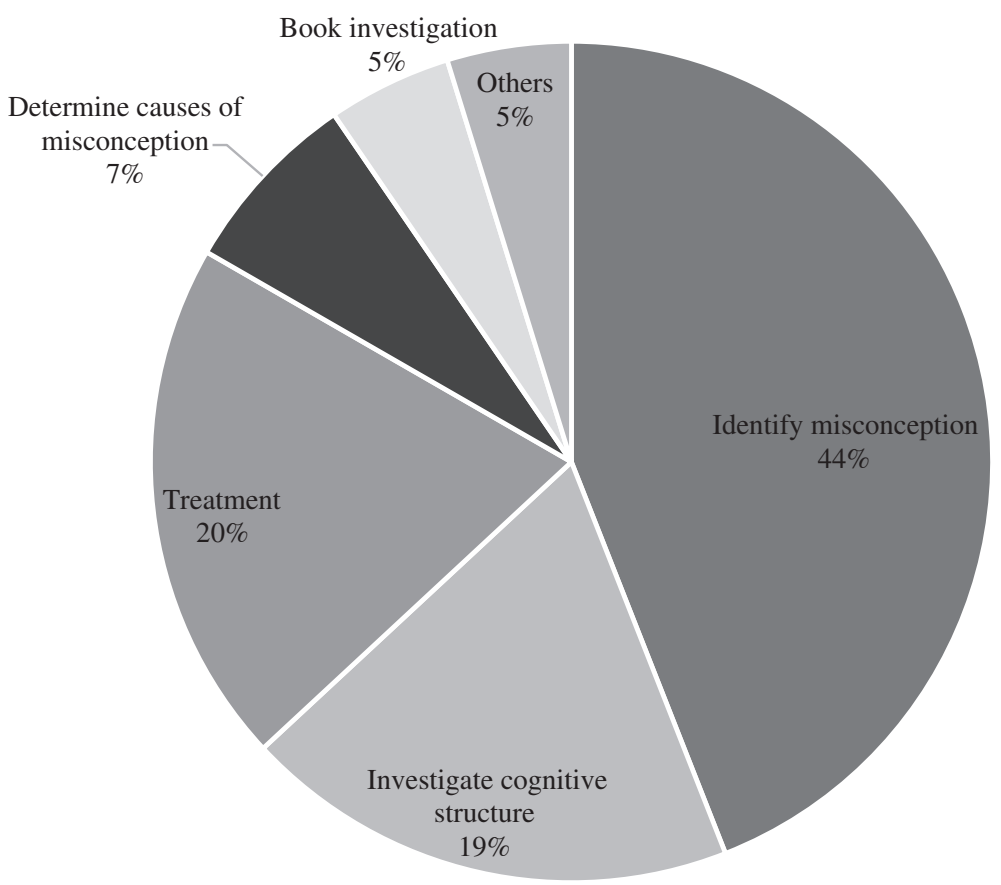

Figure 3. Purposes of research studies (\%).

mapping, conceptual change text, cooperative learning, dual situated learning model, mind map and POE (Prediction-Observation-Explanation). As seen in Table 1, concept mapping $(n=6)$ is the most popular method used to prevent or eliminate misconceptions. 
Table 1. Treatment methods.

\begin{tabular}{lcccc}
\hline & \multicolumn{3}{c}{ Year } & Total \\
\cline { 2 - 4 } & $2000-2004$ & 2005-2009 & 2010-2014 & 1 \\
\hline Analogy and modelling & 0 & 0 & 0 & 2 \\
Computer and laboratory & 1 & 1 & 2 & 2 \\
Concept cartoon & 0 & 0 & 4 & 6 \\
Concept mapping & 0 & 2 & 3 & 4 \\
Conceptual change text & 1 & 0 & 1 & 2 \\
Cooperative learning & 0 & 1 & 0 & 1 \\
Dual situated learning & 0 & 0 & 1 & 1 \\
Mind map & 0 & 0 & 2 & 2 \\
POE (Prediction-Observation-Explanation) & 0 & 5 & 14 & 21 \\
Total & 2 & & & \\
\hline
\end{tabular}

Table 2. Distribution of biology topics over the years (2000-2014).

\begin{tabular}{|c|c|c|c|c|}
\hline & \multicolumn{3}{|c|}{ Year } & \multirow[b]{2}{*}{ Total } \\
\hline & 2000-2004 & 2005-2009 & 2010-2014 & \\
\hline General topics (total) & 7 & 17 & 16 & 40 \\
\hline Biology as a science & 0 & 1 & 0 & 1 \\
\hline Biotechnology & 0 & 2 & 0 & 2 \\
\hline Chemistry of life & 1 & 3 & 2 & 6 \\
\hline Classification of living organism & 0 & 2 & 5 & 7 \\
\hline Diffusion and osmosis & 1 & 2 & 3 & 6 \\
\hline Microbiology & 0 & 0 & 3 & 3 \\
\hline Plant biology & 2 & 3 & 1 & 6 \\
\hline Respiration and photosynthesis & 3 & 4 & 2 & 9 \\
\hline Cell biology (total) & 2 & 7 & 8 & 17 \\
\hline Cell structure and organelles & 0 & 2 & 1 & 3 \\
\hline Genetic and/or cell division & 2 & 5 & 7 & 14 \\
\hline Human health and physiology (total) & 2 & 3 & 7 & 12 \\
\hline Blood circulatory system & 0 & 0 & 2 & 2 \\
\hline Digestive system & 0 & 2 & 0 & 2 \\
\hline Endocrine glands & 0 & 0 & 1 & 1 \\
\hline Excretion system & 1 & 0 & 2 & 3 \\
\hline Immune system & 0 & 0 & 1 & 1 \\
\hline Reproductive system & 1 & 1 & 1 & 3 \\
\hline Environment and ecology (total) & 5 & 5 & 6 & 16 \\
\hline Greenhouse Effect and/or global warming & 1 & 1 & 5 & 7 \\
\hline Ozone layer depletion & 0 & 1 & 0 & 1 \\
\hline World and living things & 2 & 1 & 0 & 3 \\
\hline Transformation of energy & 2 & 2 & 1 & 5 \\
\hline
\end{tabular}

The distribution of biology topics investigated over the years is given in Table 2. The topics were divided into the following areas: general, cell biology, human health and physiology, and environment and ecology. These topics were further divided into subtopics. Many of the articles focused on more than one subtopic; therefore, the total number of topics is greater than the number of articles reviewed. Most of the investigated subtopics fell within the topic of general biology $(n=40)$. There was no notable increase or decrease in which topic was investigated over the years, nor was any subtopic studied remarkably more than others. Although cell biology may be considered a general biology topic, it was pulled out into a separate subtopic because of the larger number of studies $(n=14)$ that focused on either genetics or cell division or both. This subtopic also seemed to increase in popularity over the years; while only two studies focused on cell biology during the 2000-2004 time period, their number increased to seven by 2005-2009 and nine during 2010-2014. The environment and ecology $(n=16)$ was another popular topic of investigation. Within this area, interest in the greenhouse effect and global warming increased sharply in 2010-2014. The least studied subtopics were human health and physiology. 


\section{Discussion}

The analysis of the results identified specific findings that give insights into how misconceptions were studied in Turkey from 2000 to 2014. The investigation revealed trends in the number of studies, the purpose of the investigations, target audiences, and research methods. In addition to quantifying trends and patterns in misconception research during the study period, the current study also contemplated reasons behind outcomes. Two other studies that conducted a literature review and content analysis are frequently referenced in this following discussions: Gül and Sözbilir 2015; Sözbilir and Kutu 2008. These studies looked at biology education trends in general; some of their findings provide additional insights into research related to misconceptions revealed in the current study.

\section{Trends in research studies related to biology misconceptions}

Given that misconceptions affect students' learning processes at all levels of their education, it is no surprise that studies about misconception have been increasing in the field of biology education. It was curious that there was a drop in 2014; this could merely be a result of articles being in press and not available in the search engines used for the content analysis. A post hoc search revealed that at least six studies were published in 2015.

It is possible that the focus on eliciting of misconception is declining and other topics related to improvement and application of new teaching strategies, such as project-based learning and service learning, are becoming more popular to investigate. Gül and Sözbilir (2015) and Sözbilir and Kutu (2008) report that 'teaching-focused' biology education research prevails over papers related to student learning and attitudes. It seems that investigation into the effectiveness of the variety of teaching methods has gained importance among biology researchers. There were also a large number of articles that focused on teaching attitudes about these methods (Chang, Chang, and Tseng 2010; Köse, Gül, and Konu 2014). Although the studies may not be directly about misconceptions, research into both methods and teacher attitudes can help address or avoid misconceptions and support meaningful learning.

\section{Investigative purposes}

The majority of publications analysed for this study (42.4\%) had a goal of identifying one or more misconceptions held by pre-service teachers. Studies that aimed to identify misconceptions of pre-service teachers have an important role in increasing awareness of the learning needs of pre-service teachers. The instrument used for this study did not discriminate among elementary, middle or high school pre-service teachers, mainly because reducing misconceptions in students is important for teachers of all grade levels (Larkin 2012; Tekkaya, Çapa, and Yılmaz 2000; Yakışan 2013). Several of the studies that involved pre-service teachers noted that their participants became aware of issues associated with misconceptions. They appreciate the importance of recognising and addressing misconceptions among their students when preparing their lesson plans.

The purpose of around $20 \%$ of the articles reviewed in this study was to examine how conceptual change strategies can be used to address students' incorrect scientific beliefs. Lappi (2012) defines conceptual change as a transformation of prior conception to new concepts. Conceptual change strategies are mostly used to change students' incorrect scientific beliefs. Conceptual change provides the opportunity to elicit students' prior conceptions (Fulmer 2013). Therefore, the aim of education should not only focus on eliminating the misconceptions; it should also enable students to correctly develop new information. In the literature, a number of studies have shown how these strategies are used to discover students' cognitive structures (Akyürek and Afacan 2013; Alparslan, Tekkaya, and Geban 2003; Ekici, Ekici, and Aydın 2007; Kurt 2013; Ratinen, Viiri, and Lehesvuori 2013). Other studies that have conducted content analysis of biology education teaching methods have revealed that conceptual change models are often employed in biology classes (Gül and Sözbilir 2015; Köse, Gül, and Konu 2014).

Finally, around 19\% of the reviewed articles focused on the investigation of cognitive structure. Investigation of cognitive structure aims to understand how students associate concepts in their minds 
and helps students to visualise what kind of misconceptions they have. It also shows teachers and educators the ways students think about a concept. Several studies conducted in Turkey and around the world have shown that investigation into the cognitive structure has gained importance in science research (Çakmak and Akçöltekin 2012; Cinici, Sözbilir, and Demir 2011; Kostova and Radoynovska 2010). Chang, Chang, and Tseng (2010) classified 1401 science education articles according to their research topics and reported that the articles mainly focused on students' conceptual understandings and conceptual change in the learning process. Kurt and Ekici (2013) used a word association test and the drawing-writing technique to understand pre-service teachers' cognitive structures. They sought to understand how pre-service teachers construct knowledge and how they structure the concepts in their minds, more than just what they know about the concepts.

\section{Target audiences}

Given that the purpose of most of the studies found for this review was to investigate misconceptions in pre-service teachers, it follows that the target audience in the majority of the studies (40.9\%) was pre-service teachers. Clearly, researchers are concerned that teachers' insufficient subject area knowledge and misconceptions may be an origin of misconceptions. If pre-service teachers' misconceptions are not revealed or corrected, when they become teachers they may transfer their misconceptions to students (Yangın, Sidekli, and Gökbulut 2014).

After teachers, the next most studied population were middle school students and high school students. In Turkey, biology is introduced to students in middle school in their science and technology classes. It is not until high school that they take a specific course in biology. Therefore, middle school provides a good opportunity to provide a strong foundation in biology education. A reason researchers may select this population is because this is the age when students are constructing meaning and understanding about biology; it is an ideal time to avoid misconceptions. Clough and Robinson (1985) have noted that even students who are 16 and older age group may persist to change their learning, they show improvement in their understanding and change believes about scientific incorrect ideas than from 12 to 14 years.

On the other hand, as stated at the beginning of this paper, children form many misconceptions before entering school or during their elementary school years. Unfortunately, only a few articles $(6.1 \%)$ in this review focused on elementary students' misconceptions about biology.

\section{Popularity of biology topics investigated}

A considerable proportion of the articles (18\%) focused on the topics of environment and ecology. These studies intended to identify misconceptions in order to prevent them, and to develop meaningful learning. They also sought to raise students' awareness of environmental issues. In the literature, other studies that used content analysis also determined that environment and ecology are the most studied topics in biology education in Turkey (Gül and Sözbilir 2015; Köse, Gül, and Konu 2014).

Another popular area of study (15.7\%) was genetics and cell division. Therefore, studies in this area may have increased to further understand why and how students have difficulty with these topics. In their content analysis, Asshoff and Hammann (2008) found that misconceptions in genetics and ecology were popular topics among the articles they reviewed.

\section{Gaps in research about biology topics}

One aim of the current study was to reveal gaps in the literature about research into biology misconceptions. To create a list of biology topics commonly studied in Turkish schools, the researchers referred to the Turkish Ministry of National Education biology high school curriculum. The meta-synthesis revealed that no studies investigated misconceptions in the following biology topics: 
- Nervous system

- Sensory organs

- Support and movement system

- Evolution

Moreover, although environment and ecology were popular topics to investigate, most of the studies focused on the greenhouse effect and global warming. Other topics such as biodiversity, sustainability, natural resources, and human effects on pollution were excluded. In their studies, Erdoğan, Marcinkowski, and Ok (2009) reported that environmentally responsible behaviour and socio-political knowledge received very little attention in the area of environment and ecology studies.

\section{Research methods}

Unlike other studies that have reviewed the literature, the meta-synthesis for the current study showed that a comparable number of studies used quantitative analysis methods $(n=30)$ and qualitative analysis methods $(n=29)$. Other studies found that researchers widely preferred quantitative methods in biology and science education (Erdoğan, Marcinkowski, and Ok 2009; Gül and Sözbilir 2015; Sözbilir, Kutu, and Yaşar 2012). With quantitative methods researchers can interpret the data numerically and can measure the effect of an independent variable on dependent variables (Fraenkel and Wallen 2009). Furthermore, studies that used experimental designs may aim to compare new attempts with old ones (Çalık et al. 2008).Güven et al. (2014) suggest that quantitative methods may be preferred because qualitative methods require more time to conduct. One reason why the current study may not have found a preference for quantitative methods is that the nature of misconception studies requires deeper investigation into cognitive structures than into the interpretation of numerical values.

Only a few of the studies reviewed for this content analysis used mixed methods (12\%). Mixed methods may provide even deeper understanding of the study and support the validity of the research. As Schram (2014) states, interviews with a sample group before a survey provide answers to why and how questions are answered in a certain way. This more thorough understanding can help researchers decide what to include in the survey.

\section{Data collection instruments}

Diagnostic tests and achievement tests that were developed by the researchers were the most commonly used tools to investigate students' and pre-service teachers' misconceptions in biology. Other researchers note that achievement tests are frequently used to collect data in biology education (Göktaş et al. 2012; Kızılaslan, Yaşar, and Sözbilir 2012). According to Sözbilir, Kutu, and Yaşar (2012), researchers prefer to use test-like assessments because they are easy to prepare and mark. Multiple choice type achievement tests have been found to be a popular means to assess student knowledge (Gül and Sözbilir 2015; Sözbilir, Kutu, and Yaşar 2012). Er, Ramamurthy, and Pook (2014) argue that multiple choice type questions can efficiently assess students' cognitive skills, such as analysis, synthesis and evaluation.

Although multiple choice questions can assess students' level of knowledge and cognitive skills, they may not provide enough information to discover students' cognitive structures. Test-like assessment tools only evaluate what students know, not how they came to know, about the concepts. In other words, the tests reveal there is a misconception but the researcher does not learn how it was formed or why. Furthermore, Sanders (1993) indicates that not all incorrect answers identified during research studies necessarily show students have misconceptions. He observes that while researchers perform tests during their studies and report the results accordingly, they should discriminate between true misconceptions and wrong answers. Therefore, close-ended or multiple-choice questions may not provide adequate evidence to understand students' misconceptions and their cognitive structures.

Open-ended questions (38\%) were the second most popular question types on the tests for this study. In their review of the literature and content analysis, Gül and Sözbilir (2015) reported that 
only 42 of 231 achievement tests in biology education consisted of open-ended questions. Hence, open-ended questions might be more effective at gaining insights into student misconceptions than multiple choice exams alone.

To gain even deeper insights into why learners think the way they do, many researchers use faceto-face discussions. In this study, a popular method used to collect data was through interviews. Another way researchers learned how students were thinking about a topic was through concept cartoons and roundhouse diagramming. Only a few of the studies included in the content analysis used these methods, however. Through face-to-face interactions, students may be more able to express concepts with their own words (Tatar and Cansüngü Koray 2005). Moreover, the interview format allows students to give feedback and correct any inaccurate beliefs immediately. Allen (2010) warns that despite providing more descriptive data, the researcher should be aware that there is a chance students may share what they think the researcher wants to hear instead of what they actually believe.

Regarding the number of data collection tools, most of the studies used a single data collection tool $(55.4 \%)$. There were $35.5 \%$ of the studies that used a combination of two different data tools. Other researchers that have conducted a content analysis of the literature also found that studies tend to use one data collection tool (Gül and Sözbilir 2015; Sözbilir and Kutu 2008; Sözbilir, Kutu, and Yaşar 2012). Sözbilir, Kutu, and Yaşar (2012) argue that to improve reliability and validity, more than one data collection tool should be employed. In the literature, some misconception studies use more than one data collection tool to support results (Akyürek and Afacan 2013; Cinici 2013; Kurt 2013). Perhaps using a single data collection tool in studies that investigate cognitive structures is not enough to acquire in-depth and strong results (Kurt and Ekici 2013).

\section{Conclusions}

The Paper Classification Form used in this study facilitated the meta-synthesis of research studies related to misconceptions in biology. The findings from this study indicate that publications about misconceptions in biology have been increasing in Turkey. The categories that were formed and adapted helped the researchers to analyse data in a reliable and valid way. Further research about misconceptions can be proactively guided by the results of the analysis.

The content analysis also served to identify a variety of recommendations that practitioners can use to better address student misconceptions:

- Curriculum developers, educators and teachers should give more importance to the content of biology curriculum and textbooks; they should arrange seminars or meetings to discuss and evaluate current subject matter.

- Conceptual change strategies such as concept mapping, concept cartoon, and word association test should be supported in classrooms as alternative teaching methods and assessments.

- Students' misconceptions in biology may originate from other subjects, such as chemistry, physics and physical education. Supporting interdisciplinary training with activities and examples may support students' meaningful learning and help teachers observe students' learning processes efficiently.

- Conduct more investigations into pre-service teacher misconceptions to help teacher educators become aware of misconceptions and eliminate them in their methods courses.

This review also revealed some gaps in misconception research in Turkey. Important concepts in biology, such as the nervous system, sensory organs, support and movement system and evolution were found to be under-investigated regarding misconceptions. Furthermore, the study did not learn if there were investigations into how the social environment affects students' misconceptions, how student communication influences misconceptions, and how parents affect students' misconceptions. A future study could adapt the instrument to screen for these investigations. 
Many of the findings from this meta-synthesis used in this study are relevant to other educators around the world interested in addressing student misconceptions. A main contribution of this study to the field is the adaptation and implementation of an effective tool to conduct a comprehensive content analysis of published research related to misconceptions. This tool, the Paper Classification Form (PCF), adapted from Sözbilir, Kutu, and Yaşar (2012), can be used by researchers in other countries to inventory and analyse misconception cases in their communities or regions. Using this tool can help ensure that future research proactively targets gaps in student misconception education.

\section{Disclosure statement}

No potential conflict of interest was reported by the authors.

\section{ORCID}

Armagan Ateskan (D) http://orcid.org/0000-0001-5648-2385

Jennie Lane (D) http://orcid.org/0000-0002-7763-3813

\section{References}

Akyürek, E., and Ö. Afacan. 2013. "Determination and Removal of 8th Grade Students' Misconceptions about the Unit of Cell Division and Inheritance by Using Analogy with Conceptual Change Texts." Ahi Evran Üniversitesi Krrşehir Eğitim Fakültesi Dergisi 14 (1): 175-193.

Allen, M. 2010. Misconceptions in Primary Science. Glasgow: McGraw-Hill.

Alparslan, C., C. Tekkaya, and Ö. Geban. 2003. "Using the Conceptual Change Instruction to Improve Learning." Journal of Biological Education 37 (3): 133-137.

Asshoff, R., and M. Hammann. 2008. Content Analysis of the ERIDOB Proceedings and 431 Comparison with the International Journal of Science Education. A Selection of Papers Presented at the VIIth Conference of European Researchers in Didactics of Biology (ERIDOB), Woudschoten Conference Center, Zeist, The Netherlands, September, 431-446.

Ault, C. R. 1984. "Intelligently Wrong: Some Comments on Children's Misconceptions." Science and Children 21: 22-24. Bennett, J. 2003. Teaching and Learning Science: A Guide to Recent Research and Itts Application. London: Continuum.

Bilen, K., S. Köse, and M. Uşak. 2011. “The Effect of Laboratory Activities Designed Based on Predict- Observe- Explain (POE) Strategy on Pre-Service Science Teachers' Understanding of Osmosis and Diffusion Subject." Pamukkale Üniversitesi Sosyal Bilimler Enstitüsü Dergisi 9: 115-127.

Brown, M. H., and R. S. Schwartz. 2009. 'Connecting Photosynthesis and Cellular Respiration: Preservice Teachers' Conceptions." Journal of Research in Science Teaching 46: 791-812.

Çakmak, M., and A. Akçöltekin. 2012. "8. sınıf öğrencilerinin sera etkisi hakkindaki bilgi düzeylerinin ve kavram yanilgilarinin tespit edilmesi." Dicle Üniversitesi Sosyal Bilimler Enstitüsü Dergisi 7: 144-158.

Çalık, M., and M. Sözbilir. 2014. "Parameters of Content Analysis." Education and Science 39 (174): 33-38.

Çalık, M., S. Ünal, B. Coştu, and F. Ö. Karataş. 2008. "Trends in Turkish Science Education." Essays in Education 23-46.

Caravita, S., and O. Halldén. 1994. "Re-Framing the Problem of Conceptual Change." Learning and Instruction 4 (1): 89-111.

Çelikler, D., and Z. Aksan. 2011. "Determination of Pre-Service Elementary Science Teachers' Knowledge Level about Greenhouse Effect.” Uludağ Üniversitesi Eğitim Fakültesi Dergisi 24 (1): 31-45.

Chang, Y. H., C. Y. Chang, and Y. H. Tseng. 2010. "Trends of Science Education Research: An Automatic Content Analysis." Journal of Science Education and Technology 19: 315-331.

Cinici, A. 2013. "Turkish High School Students' Ideas about Invertebrates: General Characteristics and Classification." International Journal of Environmental \& Science Education 8 (4): 645-661.

Cinici, A., M. Sözbilir, and Y. Demir. 2011. "Effect of Cooperative and Individual Learning Activities on Students' Understanding of Diffusion and Osmosis." Eurasian Journal of Educational Research 43: 19-36.

Clough, E., and C. W. Robinson. 1985. "How Secondary Students Interpret Instances of Biological Adaptation." Journal of Biological Education 19 (2): 125-130.

Driver, R. 1988. “Changing Conceptions.” Tijdschrift voor Didactiek der B-wetenschappen 6 (3): 161-197.

Driver, R. 1989. "Students' Conceptions and the Learning of Science." International Journal of Science Education 11 (5): 481-490.

Driver, R., and J. Easley. 1978. "Pupils and Paradigms: A Review of Literature Related to Concept Development in Adolescent Science Students." Studies in Science Education 5: 61-84. 
Duit, R., and D. F. Treagust. 2003. "Conceptual Change: A Powerful Framework for Improving Science Teaching and Learning." International Journal of Science Education 25 (6): 671-688.

Ekici, F., A. Ekici, and F. Aydın. 2007. "Utility of Concept Cartoons in Diagnosing and Overcoming Misconceptions Related to Photosynthesis." International Journal of Environmental \& Science Education 2 (4): 111-124.

Er, H. M., S. Ramamurthy, and P. Pook. 2014. "Can Learning Outcomes in Cognitive Domain Be Assessed Effectively Using Multiple Choice Questions? A Study in an Undergraduate Pharmacy Curriculum.” International E-Journal of Science, Medicine \& Education 8 (3): 9-18.

Erdoğan, M., T. Marcinkowski, and A. Ok. 2009. "Content Analysis of Selected Features of K-8 Environmental Education Research Studies in Turkey, 1997-2007.” Environmental Education Research 15 (5): 525-548.

Fraenkel, J. R., and N. E. Wallen. 2009. How to Design and Evaluate Research in Education. 7th ed. New York: McGraw Hill.

Fulmer, G. W. 2013. “Constraints on Conceptual Change: How Elementary Teachers' Attitudes and Understanding of Conceptual Change Relate to Changes in Students' Conceptions." Journal of Science Teacher Education 24 (7): 1219-1236.

Göktaş, Y., S. Küçük, M. Aydemir, E. Telli, Ö. Arpacık, G. Yıldırım, and İ. Reisoğlu. 2012. “Türkiye’ de Eğitim Teknolojileri Araştırmalarındaki Eğilimler: 2000-2009 Dönemi Makalelerinin İçerik Analizi.” Kuram ve Uygulamada Eğitim Bilimleri Dergisi 12 (1): 443-460.

Gül, Ş., and M. Sözbilir. 2015. “Biology Education Research Trends in Turkey.” Eurasia Journal of Mathematics, Science \& Technology Education 11 (1): 93-109.

Güneş, T., N. Ş. Dilek, E. S. Demir, M. Hoplan, and M. Çelikoğlu. 2010. "Öğretmenlerin Kavram öğretimi, Kavram Yanılgılarını Saptama Ve Giderme çalışmaları üzerine Nitel Bir Araştırma.” International Conference on New Trends in Education and Their Implications 936-944.

Güven, E., Z. Kaplan, S. Vainlioğlu, K. S. Gül, M. Hamalosmanoğlu, and O. Bozkurt. 2014. "Review of the Studies about Environmental Education: Current Status in Turkey." Necatibey Faculty of Education Electronic Journal of Science and Mathematics Education 8 (2): 1-18.

Hewson, M. G., and P. W. Hewson. 1983. "Effect of instruction Using Students' Prior Knowledge and Conceptual Change Strategies on Science Learning." Journal of Research in Science Teaching 20 (8): 731-743.

Johnstone, A. H., E. McAlpine, and P. R. P. MacGuire. 1986. "Branching Trees and Diagnostic Testing." A Journal for Further and Higher Education in Scotland 2: 4-7.

Johnston, B. M., and N. A. Mahmoud. 1980. "Isolating Topics of High Perceived Difficult in School Biology." Journal of Biological Education 14 (2): 163-166.

Kinchin, I. M. 2000. “Concept Mapping in Biology." Journal of Biological Education 34 (2): 61-68.

King, C. J. H. 2009. "An Analysis of Misconceptions in Science Textbooks: Earth Science in England and Wales." International Journal of Science Education 32: 565-601.

Kızılaslan, A., M. D. Yaşar, and M. Sözbilir. 2012. Inquiry Based Teaching in Turkey: A Content Analysis Research Reports. X. National Science and Mathematics Education Congress, Niğde.

Köse, E., Ş. Gül, and M. Konu. 2014. "The Study of Biology Education Researches Published at Ulakbim Social Sciences Database in Turkey." The Journal of Academic Social Science 2: 265-276.

Kostova, Z., and B. Radoynovska. 2010. "Motivating Students' Learning Using Word Association Test and Concept Maps." Bulgarian Journal of Science and Education Policy 4 (1): 62-98.

Krippendorff, K. 2004. Content Analysis: An İntroduction to İts Methodology. 2nd ed. Thousand Oaks, CA: Sage.

Kubisch, F., and T. Heyne. 2016. "Students' Alternative Conceptions about the Lotus Effect: To Confront or to Ignore?" Journal of Biological Education 50 (1): 86-100.

Kurt, H. 2013. "Determining Biology Student Teachers' Cognitive Structure on the Concept of Enzyme." Gazi Üniversitesi Eğitim Fakültesi Dergisi 33 (2): 211-243.

Kurt, H., and G. Ekici. 2013. "Determining Biology Student Teachers' Cognitive Structure and Alternative Concepts on the Concept of Bacteria." International Periodical for the Languages, Literature and History of Turkish or Turkic 8 (8): 885-910.

Lappi, O. 2012. "Qualitative Quantitative and Experimental Concept Possession, Criteria for Identifying Conceptual Change in Science Education." Science \& Education 22: 1347-1359.

Larkin, D. 2012. "Misconceptions about Misconceptions: Preservice Secondary Science Teachers' Views on the Value and Role of Student Ideas." Science Education 96 (5): 927-959.

Liew, C. W., and D. F. Treagust. 1995. "A Predict-Observe-Explain Teaching Sequence for Learning about Students' Understanding of Heat and Expansion of Liquids.” Australian Science Teachers'Journal 41: 68-71.

Liu, S., and G. Lee. 2013. "Using a Concept Map Knowledge Management System to Enhance the Learning of Biology." Computers \& Education 68: 105-116.

Lucero, M. M., and A. J. Petrosino. 2017. "A Resource for Eliciting Student Alternative Conceptions: Examining the Adaptability of a Concept Inventory for Natural Selection at the Secondary School Level." Research in Science Education 47 (4): 705-730.

Monteiro, A., C. Nóbrega, I. Abrantes, and C. Gomes. 2012. "Diagnosing Portuguese Students' Misconceptions about the Mineral Concept." International Journal of Science Education 34 (17): 2705-2726.

Neuendorf, K. A. 2002. The Content Analysis Guidebook. Thousand Oaks, CA: Sage. 
Novak, J. D., and R. Gowin. 1984. Learning How to Learn. 3rd ed. New York: Cambridge University Press.

Novak, J. D., and D. Musonda. 1991. "A Twelve-Year Longitudinal Study of Science Concept Learning." American Educational Research Journal 1 (28): 117-153.

Özay, E., and H. Öztaş. 2003. "Secondary Students' Interpretations of Photosynthesis and Plant Nutrition." Journal of Biological Education 37 (2): 68-70.

Pearsall, N. R., J. E. J. Skipper, and J. J. Mintzes. 1997. “Knowledge Restructuring in the Life Sciences: A Longitudinal Study of Conceptual Change in Biology." Science Education 81 (2): 193-215.

Prasad, B. D. 2008. "A Method in Social Science Research." In Research Methods for Social Work, edited by D. K. Lal Das and V. Bhaskaran, 173-193. New Delhi: Rawat.

Pugh, K., K. Koskey, and L. Linnenbrink-Garcia. 2014. "High School Biology Students' Transfer of the Concept of Natural Selection: A Mixed-Methods Approach.” Journal of Biological Education 48 (1): 23-33.

Ratinen, I., J. Viiri, and S. Lehesvuori. 2013. "Primary School Student Teachers' Understanding of Climate Change: Comparing the Results given by Concept Maps and Communication Analysis." Research in Science Education 43: 1801-1823.

Ross, B., and H. Munby. 1991. “Concept Mapping and Misconceptions: A Study of High School Students' Understanding of Acids and Bases.” International Journal of Science Education 13: 11-23.

Rotbain, Y., G. Marbach-Ad, and R. Stavy. 2008. "Using a Computer Animation to Teach High School Molecular Biology." Journal of Science Education and Technology 17 (1): 49-58.

Sanders, M. 1993. "Erroneous Ideas about Respiration: The Teacher Factor." Journal of Research in Science Teaching 30 (8): 919-934.

Schmid, R. F., and G. Telaro. 1990. “Concept Mapping as an Instructional Strategy for High School Biology." The Journal of Educational Research 84 (2): 78-85.

Schram, A. B. 2014. "A Mixed Methods Content Analysis of the Research Literature in Science Education." International Journal of Science 36 (15): 2619-2638.

Sesli, E., and Y. Kara. 2012. "Development and Application of a Two-Tier Multiple-Choice Diagnostic Test for High School Students' Understanding of Cell Division and Reproduction.” Journal of Biological Education 46: $214-225$.

Sözbilir, M., and H. Kutu. 2008. "Development and Current Status of Science Education Research in Turkey." Essays in Education 1-22. http://www.usca.edu/essays/specialedition/MSozbilirandHulyaKutu.pdf

Sözbilir, M., H. Kutu, and M. D. Yaşar. 2012. “Cultural Perspectives in Science Education.” Science Education Research and Practice in Europe: Retrospective and Prospective 5: 341-374.

Tanner, K., and D. Allen. 2005. "Approaches to Biology Teaching and Learning: Understanding the Wrong Answers Teaching toward Conceptual Change." Cell Biology Education 7: 112-117.

Tatar, N., and Ö. Cansüngü Koray. 2005. "İlköğretim 8. Sınıf öğrencilerinin Genetik ünitesi Hakkındaki Kavram Yanılgılarının Belirlenmesi.” Kastamonu Eğitim Fakültesi Dergisi 13 (2): 415-426.

Tekkaya, C. 2002. "Misconceptions as Barrier to Understanding Biology" Hacettepe Üniversitesi Eğitim Fakültesi Dergisi 23: 259-266.

Tekkaya, C., Y. Çapa, and Ö. Yılmaz. 2000. “Biyoloji öğretmen Adaylarının Biyoloji Konularındaki Kavram Yanılgıları.” Hacettepe Universitesi Ĕ̆itim Fakültesi Dergisi 140-147.

Tekkaya, C., Ö. Özkan, and S. Sungur. 2001. “Biology Concepts Perceived as Difficult by Turkish High School Students.” Hacettepe Üniversitesi Eğitim Fakültesi Dergisi 21: 145-150.

Vosniadou, S. 1994. "Capturing and Modeling the Process of Conceptual Change." Learning and Instruction 4 (1): $45-69$.

Wandersee, J. H., J. J. Mintzes, and J. D. Novak. 1994. "Research in Alternative Conceptions in Science: Part II Learning." In Handbook of Research on Science Teaching and Learning, edited by G. L. Dorothy, 177-210. New York: Macmillan Publishing Company.

Yakışan, M. 2013. “The Alternative Conceptions of Pre-Service Teachers concerning the Status of Organelles during Cell Division.” Journal of Baltic Science Education 12 (6): 813-828.

Yakışan, M., M. Selvi, and N. Yürük. 2007. "Biyoloji öğretmen adaylarinin tohumlu bitkiler hakkindaki alternatif kavramlari.” Türk Fen Eğitimi Dergisi 4 (1): 60-79.

Yangın, S., S. Sidekli, and Y. Gökbulut. 2014. "Prospective Teachers' Misconceptions about Classification of Plants and Changes in Their Misconceptions during Pre-Service Education." Journal of Baltic Science Education 13 (3): $105-117$.

Yip, D. 1998. "Identification of Misconceptions in Novice Biology Teachers and Remedial Strategies for Improving Biology Learning." International Journal of Science 4 (20): 461-477. 


\section{Appendix 1. Paper Classification Form}

This instrument was prepared to guide the content analysis for the current study. There are seven main parts and each is designed to gather information about the specific features of the documents. Used and adapted with permission from Sözbilir, Kutu, and Yaşar (2012).

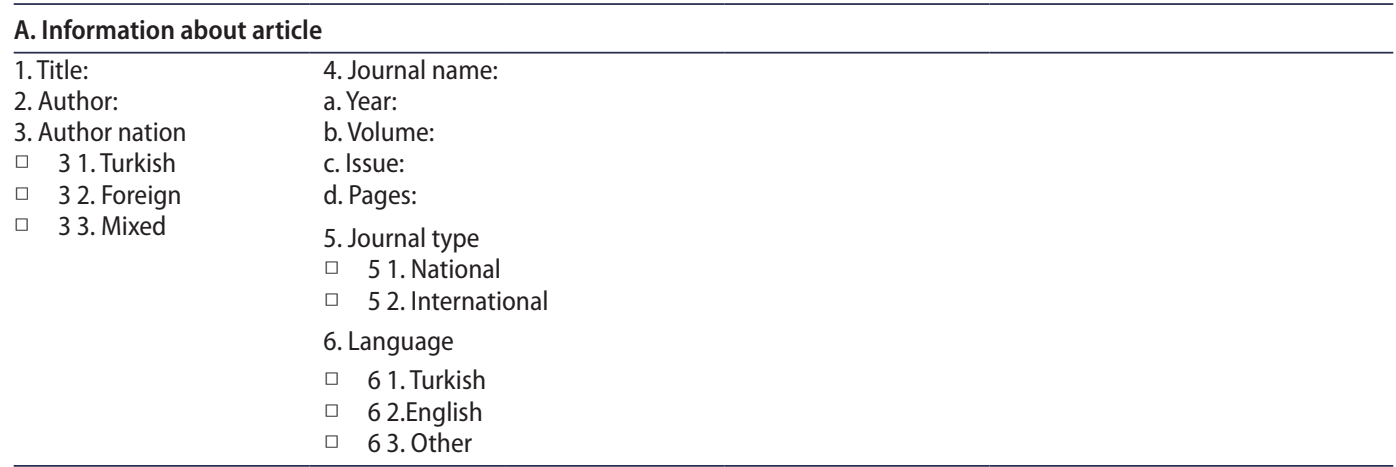

\section{B. Target of the article}

$\square \quad$ 1. Investigate cognitive structure

2. Treatment

$\square \quad 3$. Identify misconception

$\square \quad$ 4. Conceptual understanding difficulties

5. Determine causes of misconception

․ 6. Book investigation

$\square \quad$ 7. Other

Please write the title.

\section{Topic}

$\square \quad$ 1. Biology as a science

$\square \quad$ 2. Cell biology

$\square \quad$ 2.1. Cell structure and organelles

$\square \quad$ 2.2. Diffusion and osmosis

- 3. Genetic and/or cell division

$\square$ 4. Biotechnology

$\square \quad$ 5. Chemistry of life

$\square \quad$ 6. Classification of living organism

$\square \quad$ 7. World of living creatures
$\square \quad$ 7.1. Microbiology

$\square \quad$ 7.2. Plant biology
$\square \quad$ 8. Human health and physiology
$\square \quad$ 8.1. Endocrine glands
8.2. Immunity
ㅁ 8.3. Excretion system
- 8.4. Blood circulatory system
$\square \quad$ 8.5. Reproductive system
8.6. Digestive system
$\square \quad$ 9. Environment and ecology
9.1. Greenhouse effect and/or global warming
$\square$ 9.2. Ozone layer depletion
$\square$ 9.3. World and living things
$\square$ 9.4.Transformation of energy
$\square \quad$ 10. Respiration and photosynthesis

\section{Research Method}
1.Quantitative
$\square \quad$ 2. Qualitative
$\square \quad$ 3. Mixed 


\section{E. Data Collection Tools}

\section{A. Number of data collection tools}

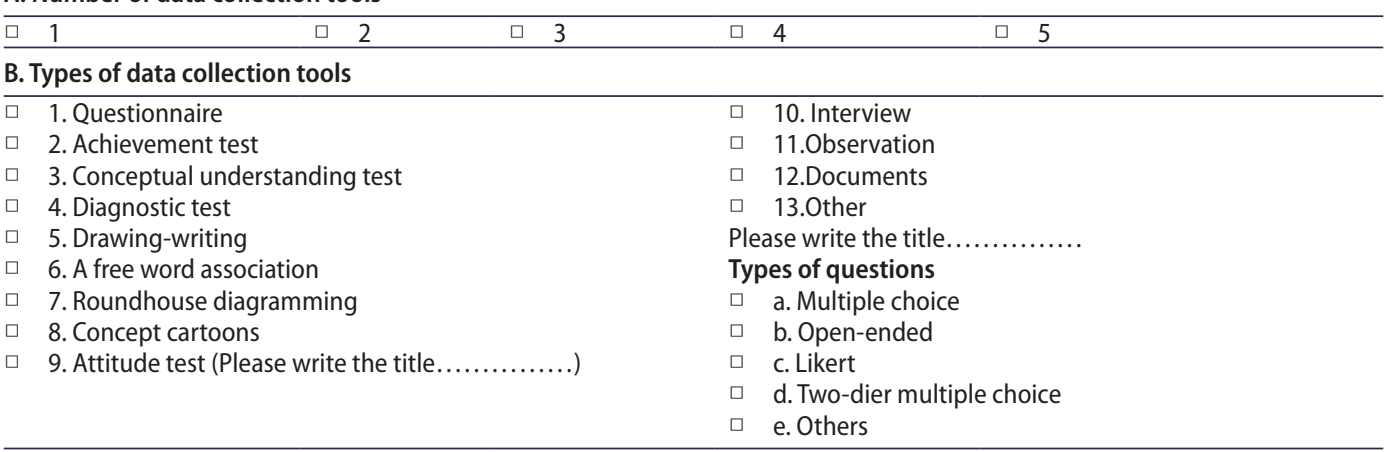

\section{F. Sample}

\begin{tabular}{ll}
\hline A. Sample & B. Sample size \\
$\square \quad$ 1. Pre-service teachers & $\square \quad$ 1. Between 1 to 10 \\
$\square \quad$ 2. Elementary school (1-4 grades) & $\square \quad$ 2. Between 11 to 30 \\
$\square \quad$ 3. Middle school (5-8 grades) & $\square \quad$ 3. Between 31 to 100 \\
$\square \quad$ 4. High school (9-12 grades) & $\square \quad$ 4. Between 101 to 300 \\
$\square \quad$ 5. Others & $\square \quad$ 5. Between 301 to 1000 \\
Please write the title................ & $\square \quad 6$. Over 1000
\end{tabular}

\section{G. Data Analysis}

1. Quantitative

2. Qualitative $\square \quad$ 11. Descriptive statistics (frequency/percentage tables, charts, central tendency measures)

12. Inferential statistics ( $t$-test, ANOVA/ANCOVA, correlation, factor analysis, regression) 